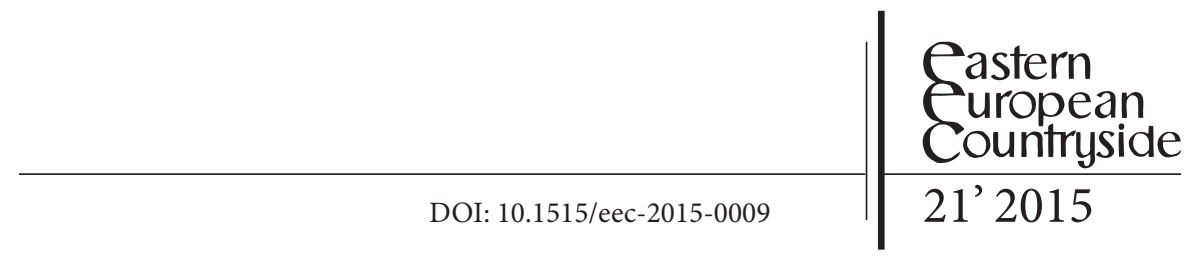

Laszlo Kulcsar Jr.

\title{
Coerced Modernization in the Eastern European Countryside
}

Mungiu-Pippidi A. (2010), A Tale of Two Villages. Coerced Modernization in the East European Countryside, CEU: Budapest-New York, pp. 232.

Somehow the issues of the Eastern European countryside always seem to be more interesting and exotic than the urban problems of the region. Part of this may come from the fact that rural Eastern Europe evokes a number of emotional perspectives, such as being the cradle of local traditions, the hated baggage of national modernization, the breeding ground of conservative ideology or the last remaining bastion against the global cultural decline. Whether these are true or not is a different question, but any study of rural Eastern Europe in a historical perspective would likely touch on a number of these themes, offering a memorable journey in the periphery.

The tale of two Romanian villages by Alina Mungiu-Pippidi is no exception. The book tells the story of Nucsoara and Scornicesti, two villages that were once reasonably similar, but took markedly different development paths in the $20^{\text {th }}$ century. Nucsoara was the center of a unique but isolated and largely unsuccessful anti-communist resistance, and suffered through the injustice of retribution while largely having been neglected in communist resource redistribution. Scornicesti was the birthplace of 'The Genius of the Carpathians', a burden in itself, and it suffered through the enforced systematization of communist urbanization as a pilot case. These parallel 
histories open up the possibility to discuss common themes along the two different trajectories, offering an interesting narrative to tell.

Chapter 1 provides the conceptual argument, while chapter 2 offers the historical background. Chapters 3 through 7 are less obvious in their structure, mixing the thematic approach (land tenure, elite change and reproduction, local politics) with place-specific pieces of the discussion and the account of change over time. This was probably not the best way to construct the narrative, as the rich details would have required a bit more structure from the author (chapter 7 seems particularly out of place). Chapter 8 then is the conclusion with some speculations about the future, including the evergreen topic of European Union accession albeit with a tone resembling to Fukuyama's end of history thesis when claiming that this is the last phase of modernization.

The story is extremely interesting to read, written in the best traditions of rural ethnography. I particularly enjoyed the very long quotes that contributed to the authenticity of the argument. Too many authors shy away from giving enough voice to their interviewees in the final product, but this book utilized the personal accounts with great efficiency to highlight the details of the context. I wish there were some visuals on the villages, either pictures or maps, to help the reader, but that is a minor issue overall.

The book should receive praise for two specific scholarly accomplishments. The first is the discussion of elite change and reproduction in a rural context. A lot had been written on elite change in both the 1950s and the 1990s, but how this happened in rural places was left largely uncovered. Well utilizing the historical ethnographic approach, and especially that both places were relatively small, the account of elite dynamics is one of the most fascinating parts of the narrative. The social structures of peasant communities have remained largely frozen in time until the communist takeover. Village elites have been reproduced from the same occupations and landholding families that were obviously unacceptable for the communists. However, the pool of alternative solutions was somewhat limited, to which the communist answer was to engineer social conflict to clearly designate comrades and enemies, amplifying the differences, and recruiting the future cadres from the poorest strata of rural societies, the ones with the most to feel angry about. This was mostly done along the line of land tenure, the chief asset and the source of most conflict in small villages (although with important differences between the two villages, due to their collectivization experiences). This 
elite transformation was very different from those in urban areas, and Mungiu-Pippidi's book provides an interesting example for this.

Another set of excellent insights discuss systematization, the most perverse example of communist social engineering in urban development. The large scale destruction of homes to develop agro-industrial rural towns while deliberately breaking the social structure of traditional communities was a combined economic and political agenda. It did fit the general functionalist teachings of Soviet style regional development, in which small places were deemed unsustainable and backward. However, no other communist country in Eastern Europe has gone to the extreme Romania did.

Mungiu-Pippidi mentions the 1989 open letter against razing small villages, and I do remember that back at that time nothing galvanized the Hungarian anti-communist opposition more than the destruction of ethnic Hungarian villages in Transylvania. This symbolic intention of Ceausescu, as he had little time to actually achieve what he wanted, provided an incredible amount of energy for those rising against communism in Hungary probably not what the Genius of the Carpathians had in mind. However, I am fairly certain that nobody protesting in front of the Romanian embassy in Budapest around 1988-89 knew that systematization has already took place in the birthplace of the dictator himself, as a test case, executed by the planners responsible for destroying the old downtown of Bucharest.

In chapter 6 Mungiu-Pippidi gives a vivid account of how this experiment took place in the 1970s. The start had all the elements of classic planning practices at that time, infused with almost comical misunderstandings that are typical for tight dictatorships (the don't touch the road element, which by the way could have come from a Jiri Menzel movie). It was a tragic outcome for the families that were uprooted to leave country life behind for collective 'modern amenities' that were never fully developed, triggering a specific rural version of what Konrad and Szelenyi called under-urbanization. This experiment which largely destroyed the old Scornicesti should belong to the darkest pages in the history of communism. It was ultimately a failure as subsistence plots came back and rural industrialization collapsed (see the Pulsor story), but as Mungiu-Pippidi noted, the main casualty of the process was the public itself. If there was anything systematized in Scornicesti, it was the disappointment, bitterness and apathy of the locals. 
While the book delivers the local stories with incredibly rich details, it suffers from a lack of an overarching conceptual framework. MungiuPippidi combines the perspectives of anthropology and political science to discuss the villages across two major social and economic transformations. This is not a marriage made in heaven. On the one hand, political science has obvious troubles using ethnographic tools to account for major structural changes, and the integration of national and local political changes has not been seamless in the book. On the other hand, anthropology has an inherent weakness when it comes to offering a framework for broad societal changes, particularly when trying to accommodate a political economy perspective. In this particular case, anthropology has won the day. One can read the book as a loose collection of excellent ethnographic pieces that reveal a lot about local social change over the decades. Putting all this change into a structured framework was a much less successful attempt, which is the most obvious in chapters 1 and 7.

Chapter 1, called 'The Argument' misses a lot of the academic discourse on both communist and post-socialist modernization and development, as well as the theoretical links to globalization or European accession, despite that these debates have been very prominent in the 1990s. As such, this creates a somewhat weak conceptual setup for the book. Chapter 7 provides a lot of the background information, such as population dynamics and urban-rural differences, which should have been part of chapter 1 to set the context. In chapter 7 they look little more than an afterthought, long after the real story has been told. The theme of chapter 7 , the transformation of the dependent peasant strata to a citizen-peasant or neo-dependent local society is an interesting thesis, but it lacks the broader discussion on how the countryside itself has actually changed after the fall of communism. Agriculture and land ownership have lost a lot of ground as focal points in the individual or collective measures of success after the very emotional years of land restitution in the early 1990s. This is the clearest in the main factors Mungiu-Pippidi lists as causes of the replication of the interwar political structure: four of the seven are directly related to agriculture, two are addressing state subsidies, and the last is on political illiteracy. It is somewhat unfortunate that this fascinating example of political, social and economic underdevelopment in the countryside, which Ivan Berend called the detour from the periphery to the periphery, missed the opportunity to 
be situated and elaborated in the framework of the scholarship on broad social change in the region.

Nonetheless, this is a very interesting book to read about the rural context of the $20^{\text {th }}$ century political turmoil. It helps understanding the challenges and failures of the post-communist transformation. Behind every macro-level change, there are local stories to tell, and the tales of Nucsoara and Scornicesti take the reader deep inside the chaos and folly of coerced modernization in the Eastern European countryside. 